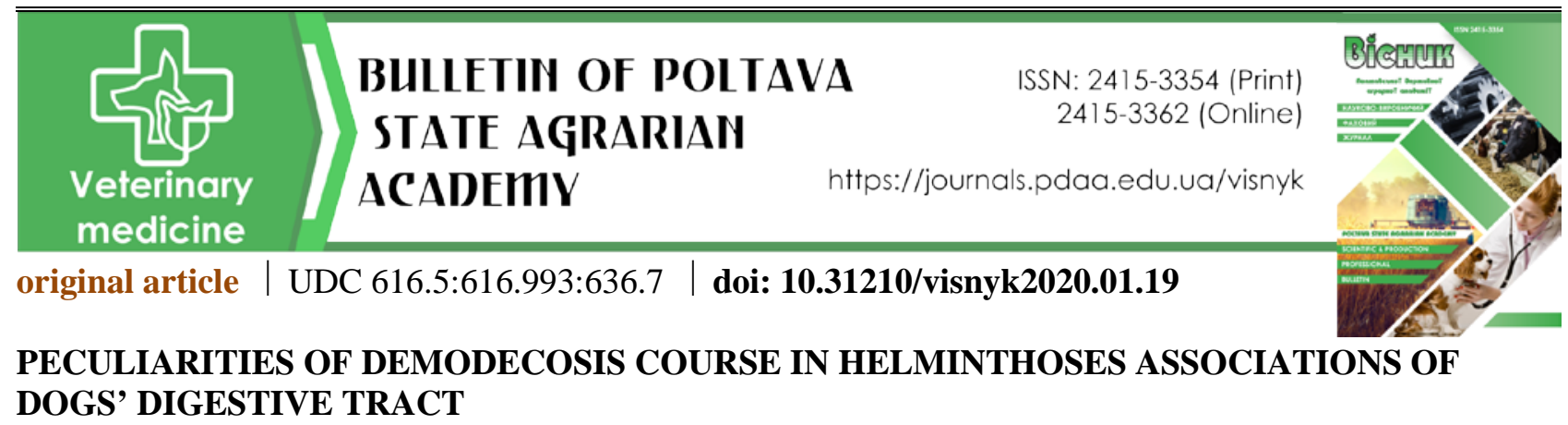

V. O. Yevstafieva*

ORCID (D) 0000-0003-4809-2584

A. S. Lychman

Poltava State Agrarian Academy, 1/3, Skovorody str., Poltava, 36003, Ukraine

*Corresponding author

E-mail: evstva@ukr.net

Demodecosis invasion occupies a particular place among the diseases of pets. Most often dogs are affected by the disease and it can cause considerable economic losses to dog breeding. At the same time, demodecosis has social importance, as dogs constantly contact with their owners. Demodecosis is widely spread in many European countries including Ukraine, where the invasion tends to constant spreading as a result of increasing the number of carnivorous animals, especially in cities and towns. The studies were conducted in the laboratory of the Department of Parasitology and Veterinary-Sanitary Expert Examination of Poltava State Agrarian Academy. The aim of the research was to investigate the peculiarities of demodecosis course in the helminthoses of dog digestive tract and determine the main associates of mixed invasions. Dogs' skin scrapings studies were conducted by vital method. Helminth oovoscopy of dogs' feces samples infected with Demodex canis was made by Kotelnikov-Khrenov's method. According to the results of dogs' acarological studies, it was established that the average prevalence of demodecosis invasion made $21.43 \%$ among the animal skin pathologies in the town of Poltava. Mixed invasions were presented by twocomponent and three-component associations of parasites, namely: Demodex canis (Leydig, 1859), Trichuris vulpis (Frölich, 1789), and Uncinaria stenocephala (Railliet, 1884), in different combinations. Most often, demodecosis-trichurosis invasion was detected (54.55 of all the revealed mixed invasions). Demodecosisuncinariosis (27.27\%) and demodecosis-trichurosis-uncinariosis (18.18\%) invasions were registered less frequently. It was determined that demodecosis was manifested both as mono-invasion in infected dogs (47.62\%) and association with intestinal nematodoses (52.38\%). Two-component mixed invasions dominated, in which the indices of prevalence reached $42.86 \%$. Three-component invasion was revealed only in $9.52 \%$ of dogs diseased with demodecosis. The obtained results of studies supplement the existing data as to the course of dog demodecosis and will also enable to conduct complex treatment of demodecosis associative course.

Keywords: demodecosis, dogs, associative course, helminthoses, prevalence.

\title{
ОСОБЛИВОСТІ ПЕРЕБІГУ ДЕМОДЕКОЗУ У СКЛАДІ ГЕЛЬМІНТОЗІВ ТРАВНОГО КАНАЛУ СОБАК
}

\section{B. О. Свстаф'єва, А. С. Личман,}

Полтавська державна аграрна академія, м. Полтава, Україна

Серед хвороб домашніх непродуктивних тварин особливе місие займає демодекозна інвазія. Найчастіше хвороба уражує собак і може спричинювати суттєві економічні збитки собаківництву. Водночас демодекоз має й сочіальне значення, оскільки собаки постійно перебувають у контакті з їхніми власниками. Демодекоз собак має значне розповсюдження в багатьох європейських краӥнах, зокрема в Украӥні, де інвазія має тендениію до постійного поширення внаслідок збільшення чисельності м'ясоїдних тварин, особливо в містах. Дослідження виконували на базі лабораторії кафедри пара- 


\section{ВЕТЕРИНАРНА МЕДИЦИНА}

зитологї та ветеринарно-санітарної експертизи Полтавської державної аграрної академії. Метою роботи було дослідити особливості перебігу демодекозу у складі гельмінтозів травного каналу собак, визначити основних співчленів мікстінвазій. Дослідження зіскрібків зі шкіри собак проводили вітальним методом. Гельмінтоовоскопію проб фекалій собак, інвазованих Deтодех сапіs, проводили за методом Котельникова-Хренова. За результатами акарологічних досліджень собак встановлено, що середня екстенсивність демодекозної інвазії в місті Полтаві серед патологій шкіри тварин становила 21,43\%. Визначено, що демодекоз у інвазованих собак перебігає як моноінвазія (47,62\%), так і в асоціаиії з кишковими нематодозами (52,38\%). Мікстінвазії були представлені двокомпонентними та трикомпонентними асоціаціями паразитів, а саме: Demodex canis (Leydig, 1859), Trichuris vulpis (Frölich, 1789) ma Uncinaria stenocephala (Railliet, 1884), щуо мали різні комбінаиії. Найчастіше виявляли демодекозно-трихурозну інвазію (54,55\% від усіх виявлених мікстінвазій). Рідше реєстрували демодекозно-унцинаріозну (27,27\%) та демодекозно-трихурозно-унцинаріозну (18,18\%) інвазії. Домінували двокомпонентні мікстінвазії, де показники екстенсивності інвазії сягали 42,86\%. Трикомпонентну інвазію встановлено лише у 9,52 \% хворих на демодекоз собак. Отримані результати досліджень розширяють уже наявні дані щодо перебігу демодекозу в собак, а також дають змогу проводити комплексне дослідження тварин та призначати комплексне лікування у разі асоиіативного перебігу демодекозу.

Ключові слова: демодекоз, собаки, асоиійований перебіг, гельмінтози, екстенсивність інвазії.

\section{ОСОБЕННОСТИ ТЕЧЕНИЯ ДЕМОДЕКОЗА В СОСТАВЕ ГЕЛЬМИНТОЗОВ ПИЩЕВАРИТЕЛЬНОГО ТРАКТА СОБАК}

\section{В. А. Евстафьева, А. С. Лычман,}

Полтавская государственная аграрная академия, г. Полтава, Украина

Проведенные исследования показали, что средняя экстенсивность демодекозной инвазии собак на территории города Полтавы среди патологий кожи составила 21,43 \%. Демодекоз у инвазированных собак протекает как в виде моноинвазии (47,62\%), так и в виде ассочиачии с кишечными нематодозами (52,38\%). Микстинвазии были представлены двухкомпонентными и трехкомпонентными ассоџиациями паразитов, а именно: Demodex canis (Leydig, 1859), Trichuris vulpis (Frölich 1789) u Uncinaria stenocephala (Railliet, 1884). Чаще всего выявляли демодекозно-трихурозную инвазию (54,55\% от общего числа выявленных микстинвазий). Реже регистрировали демодекозноунцинариозную $(27,27 \%)$ и демодекозно-трихурозно-унцинариозную $(18,18 \%)$ инвазии. Доминировали двухкомпонентные микстинвазии, где показатели экстенсивности инвазии достигали 42,86\%.

Ключевье слова: демодекоз, собаки, ассоциированное течение, гельминтозы, экстенсивность инвазии.

Вступ

Серед хвороб домашніх непродуктивних тварин на урбанізованих територіях особливе місце займає демодекозна інвазія. Найчастіше хвороба уражує собак і може спричинювати суттєві економічні збитки службовому і мисливському собаківництву. Водночас демодекоз має й соціальне значення, оскільки собаки постійно перебувають у контакті з їхніми власниками і членами їхніх сімей, що характерно для великих міст. Насамперед це пов'язано зі збільшенням темпів і обсягу безконтрольного розведення собак різних порід, ввезенням 3-за кордону самців-плідників, а також неправильними умовами годівлі та утримання тварин [1-4].

Більшість дослідників свідчать, що найбільш широкими територіальними межами характеризується епізоотичний процес у разі демодекозу у тварин, де сприйнятливими можуть бути парнокопитні, м'ясоїдні, всеїдні, хижаки, домашні й дикі тварини, а також людина [5, 6]. Демодекоз встановлено в Австралії в тигра [7], у чорних ведмедів на території США [8], у каліфорнійських білок [9], у гірських козлів у Чехії [10].

Демодекоз собак має значне розповсюдження в багатьох європейських країнах, зокрема в Україні, де інвазія має тенденцію до постійного поширення внаслідок збільшення чисельності м'ясоїдних тварин, особливо в містах [11-13].

Дослідники встановили, що джерелом збудника демодекозу є інвазовані тварини. Передача кліщів у популяції того чи того виду тварин і на міжпопуляційному рівні здійснюється при прямому контак- 


\section{ВЕТЕРИНАРНА МЕДИЦИНА}

ті тварин або через предмети догляду, спецодяг обслуговуючого персоналу, обладнання $[14,15]$. Відомо, що це хронічне захворювання, яке характеризується запаленням і десквамацією рогового шару шкіри, зниженням імунного статусу організму, вираженим виснаженням тварини. Демодекоз собак може перебігати в кількох клінічних формах. При цьому має значення характер патологічних змін шкіри, локалізація і площа уражень, вік тварини $[16,17]$. Водночас $є$ повідомлення в науковій літературі, що демодекси в обмеженій кількості є сапрофітами шкіри людей і тварин та не завжди спричинюють клінічні ознаки хвороби [18-20].

Зважаючи на вищенаведене, метою нашої роботи було дослідити особливості перебігу демодекозу собак у складі гельмінтозів травного каналу.

Для досягнення мети необхідно розв'язати такі задачі: встановити показники інвазованості собак збудником демодекозу, дослідити основних співчленів мікстінвазій собак.

\section{Матеріали і методи досліджень}

Робота виконана впродовж 2019-2020 pр. на базі лабораторії кафедри паразитології та ветеринарно-санітарної експертизи Полтавської державної аграрної академії. Вивчення поширення та особливостей перебігу демодекозу собак на території міста Полтави проводили за результатами акарологічних копроовоскопічних досліджень тварин. Експериментальна частина роботи проводилася згідно із «Загальними етичними принципами експериментів на тваринах», схваленими на Національному конгресі з біоетики (Київ, 2001) з дотриманням міжнародних вимог Свропейської конвенції «Про захист хребетних тварин, що використовуються для дослідних та інших наукових цілей» (Страсбург, 1986).

Усього досліджено 98 собак різних вікових груп та порід. При паразитологічному обстеженні тварин визначали показник їх ураження збудниками демодекозу та гельмінтозів - екстенсивність інвазії (EI, \%). Для лабораторного підтвердження демодекозу з кількох уражених ділянок на межі зі здоровою шкірою робили глибокі, до появи крові, зіскрібки, які розглядали під малим збільшенням мікроскопа. Матеріал досліджували вітальним методом з додаванням рослинної олії. Наявність у матеріалі кліща Demodex canis на різних стадіях розвитку слугувала підставою для постановки діагнозу на демодекоз. Гельмінтоовоскопію проб фекалій проводили за методом Котельникова-Хренова [21]. Визначення видової належності яєць гельмінтів проводили за допомогою атласу диференціальної діагностики гельмінтозів тварин [22].

\section{Результати досліджень та їх обговорення}

Результати проведених паразитологічних досліджень свідчать, що середня екстенсивність демодекозної інвазії собак серед патологій шкіри на території міста Полтави становить 21,43 \% за інтенсивності інвазії від 1 до 3 кліщів у зіскрібку зі шкіри.

Визначено, що демодекоз у інвазованих собак перебігає як моноінвазія - 47,62 \% (10 голів), так і в асоціації з кишковими нематодозами - 52,38 \% (11 голів) (рис. 1).

\section{Моноінвазія $\square$ Асоціативний перебіг демодекозу}

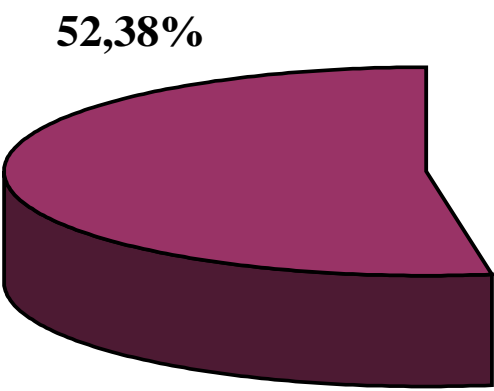

\section{$47,62 \%$}

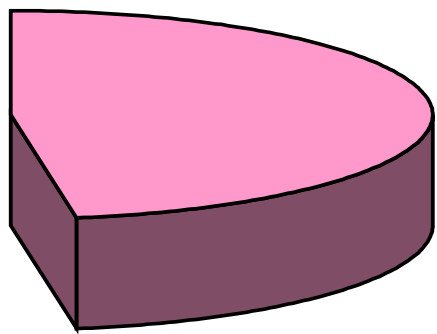

Рис. 1. Форми перебігу демодекозу собак 


\section{ВЕТЕРИНАРНА МЕДИЦИНА}

Мікстінвазії були представлені двокомпонентними та трикомпонентними асоціаціями паразитів, а came: Demodex canis (Leydig, 1859), Trichuris vulpis (Frölich 1789) та Uncinaria stenocephala (Railliet, $1884)$ у різних комбінаціях. Найчастіше виявляли демодекозно-трихурозну інвазію $(54,55 \%$ від всіх виявлених мікстінвазій, ЕI - 28,57 \%). Рідше реєстрували демодекозно-унцинаріозну $(27,27 \%$, ЕI 14,29 \%) та демодекозно-трихурозно-унцинаріозну (18,18 \%, ЕІ - 9,52 \%) інвазії (табл., рис. 2).

Демодекоз у складі мікстінвазій кишкового каналу собак $(\mathrm{n}=21)$

\begin{tabular}{|c|c|c|c|}
\hline Асоціації паразитів & $\begin{array}{c}\text { Інвазовано, } \\
\text { гол. }\end{array}$ & $\begin{array}{c}\text { \% від хворих на мікстін- } \\
\text { вазії }(\mathrm{n}=11)\end{array}$ & $\begin{array}{c}\text { EI, } \\
\%\end{array}$ \\
\hline Двокомпонентні: & 9 & 81,82 & 42,86 \\
\hline Демодекоз + трихуроз & 6 & 54,55 & 28,57 \\
\hline Демодекоз + унцинаріо & 3 & 27,27 & 14,29 \\
\hline Трикомпонентна: & 2 & 18,18 & 9,52 \\
\hline $\begin{array}{c}\text { Демодекоз + трихуроз } \\
\text { унцинаріоз }\end{array}$ & 2 & 18,18 & 9,52 \\
\hline
\end{tabular}
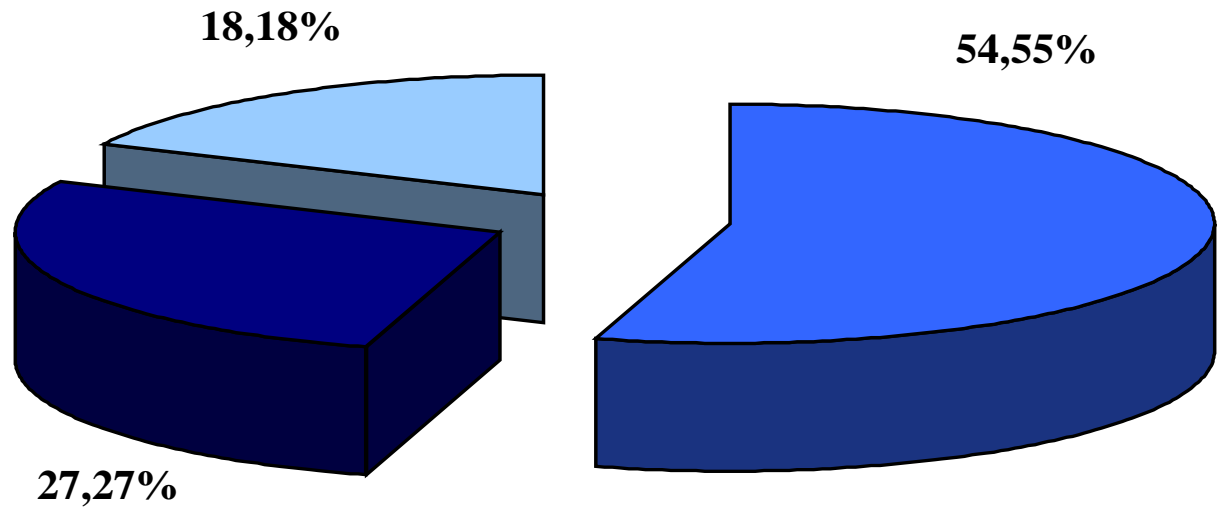

$27,27 \%$

$\square$ Д+Т $\quad \square$ Д+У $\quad \square$ 口+ $+\mathrm{Y}$

Рис. 2. Особливості перебіzу Deтоdex сапіs у складі нематодозів киикового каналу собак: Д-демодекоз, $Т$ - трихуроз, У-унцинаріоз

Домінували двокомпонентні мікстінвазії, де показники екстенсивності інвазії сягали 42,86 \%, що становило 81,82\% від хворих на мікстінвазії собак. Трикомпонентну інвазію встановлено лише у 9,52 \% хворих на демодекоз собак.

Літературні дані свідчать про значне поширення та небезпеку збудника демодекозу серед популяції домашніх собак. На думку більшості дослідників, D. сапіs входить до складу нормальної шкірної фауни в собак, а клінічні прояви хвороби виникають, якщо в роботі імунної системи організму є порушення, вроджені чи набуті, що призводить до розмноження кліщів. Наприклад, на території Індії ураженість собак збудником демодекозу становила 31,42 \% [16], у Непалі - до 70 \% [23], на території Китаю - 13,31 \% [11], у Тайвані - до 12,5 \% [24]. Проведені дослідження свідчать про значне поширення демодекозу собак на території міста Полтави (Україна), де екстенсивність інвазії серед патологій шкіри становила 21,43 \%. Це підтверджує результати більшості науковців світу, що свідчить про широке розповсюдження демодекозу серед м'ясоїдних тварин. Також ми виявили, що демодекоз у інвазованих собак перебігає як моноінвазія (47,62 \%), так і в асоціації з кишковими нематодозами (52,38 \%). Мікстінвазії були представлені асоціаціями паразитів, а саме: Demodex canis (Leydig, 1859), Trichuris vulpis (Frölich, 1789) та Uncinaria stenocephala (Railliet, 1884). Домінували двокомпонентні мікстінвазії, де показники екстенсивності інвазії сягали 42,86 \%. Трикомпонентну інвазію встановлено лише у 9,52 \% хворих на демодекоз собак. 


\section{ВЕТЕРИНАРНА МЕДИЦИНА}

У літературних джерелах є окремі повідомлення щодо асоціативного перебігу демодекозу з трихофітією [25], а також з ектопаразитами видів Otodectes cynotis, Sarcoptes scabiei var canis, Ctenocephalides canis i Trichodectes canis, які перебігали як дво- й більше компонентні мікстінвазії [26].

Отримані результати досліджень розширяють уже наявні дані щодо перебігу демодекозу в собак, а також дають змогу проводити комплексне дослідження тварин та призначати комплексне лікування у разі асоціативного перебігу демодекозу.

\section{Висновки}

Результати проведених досліджень свідчать, що в місті Полтава демодекоз собак є поширеною інвазією. Серед патологій шкіри тварин екстенсивність інвазії Demodex canis становить 21,43 \%. Водночас визначено, що демодекоз собак у 47,62 \% перебігає як моноінвазія, у 52,38 \% - як мікстінвазія. Demodex canis редєструється у дво- та трикомпонентних асоціаціях разом 3 нематодами Trichuris vulpis та Uncinaria stenocephala.

Перспективи подальших досліджень. У подальших дослідженнях плануємо вивчити ефективність лікувальних засобів за наявності демодекозу в собак.

\section{References}

1. Morsy, T. A., el Okbi, M. M., el-Said, A. M., Arafa, M. A., \& Sabry, A. H. (1995). Demodex (follicular mite) infesting a boy and his pet dog. Journal of the Egyptian Society of Parasitology, 25 (2), 509-512.

2. Sivajothi, S., Reddy, B. S., \& Rayulu, V. C. (2015). Demodicosis caused by Demodex canis and Demodex cornei in dogs. Journal of Parasitic Diseases, 39 (4), 673-676. doi: 10.1007/s12639-013-0405-3.

3. Shoop, S. J., Marlow, S., Church, D. B., English, K., McGreevy, P. D., Stell, A. J., Thomson, P. C., O'Neill, D. G., \& Brodbelt, D. C. (2015). Prevalence and risk factors for mast cell tumours in dogs in England. Canine Genetics and Epidemiology, 2, 1. doi: 10.1186/2052-6687-2-1.

4. Sgarbossa, R. S., Sechi, G. V., Pacheco, B. D., Lucina, S. B., Paulo, M. R., Monti, F. D., \& Farias, M. R. (2017). The epidemiological and clinical aspects of Demodex injai demodicosis in dogs: a report of eight cases. Semina: Ciencias Agrarias, 38 (5), 3387-3393. doi: 10.5433/16790359.2017v38n5p3387.

5. Bukva, V. (1995). Demodex species (Acari: Demodecidae) parasitizing the brown rat, Rattus norvegicus (Rodentia): redescription of Demodex ratti and description of $D$. norvegicus sp. n. and D. ratticola sp. n. Folia Parasitologica, 42 (2), 149-160.

6. Forrester, D. J., \& Wooding, J. B. (1993). Demodicosis in blaek bears (ursus americanus) from Florida. Journal of Wildlife Diseases, 29, 136-138. doi: 10.7589/0090-3558-29.1.136.

7. Junk, A. K., Lukacs, A., \& Kampik, A. (1998). Topicax administration of mitronidazole gel asan effectiye therapy alternative in chronic Demodex blefaritis - a case report. Klinische Monatsblätter für Augenheilkunde, 213 (1), 48-50. doi: 10.1055/s-2008-1034943.

8. Foster, G. W., Cames, N. A., \& Forester, D. I. (1998). Geographical distribution of Demodex ursi in black bears from Florida. Journal of Wildlife Diseases, 34 (1), 161-164. doi: 10.7589/0090-3558-34.1.161.

9. Waggie, K. S., \& Marion, P. L. (1997). Demodex sp. in California ground squirrels. Journal of Wildlife Diseases, 33 (2), 368-370. doi: 10.7589/0090-3558-33.2.368.

10. Fleischer, P., Lukesová, D., Skrivánek, M., Hofírek, B., \& Stursa, I. (1996). First report of demodicosis in goats in the Czech Republic. Veterinary Medicine, 41 (9), 289-293.

11. Chen, Y., Lin, R., Zhou, D., Song, H., Chen, F., Yuan, Z., Zhu, X., Weng, Y., \& Zhao, G. (2012). Prevalence of Demodex infection in pet dogs in Southern China. African Journal of Microbiology Research, 6 (6), 1279-1282. doi: 10.5897/AJMR11.1530.

12. Galat, V., \& Tytarenko, A. (2004). Epizootologija ta klinichni projavy demodekoznoi invazii u sobak. Veterynarna Medycyna Ukrai'ny, 12, 36-37 [In Ukrainian].

13. Martínez-Subiela, S., Bernal, L. J., Tvarijonaviciute, A., Garcia-Martinez, J. D., Tecles, F., \& Cerón, J. J. (2014). Canine demodicosi: the relationship between response to treatment of generalised disease and markers for inflammation and oxidative status. Veterinary Dermatology, 25, 72-76. doi: 10.1111/vde.12108.

14. O'Neill, D. G., Turgoose, E., Church, D. B., Brodbelt, D. C., \& Hendricks, A. (2020). Juvenile-onset and adult-onset demodicosis in dogs in the UK: prevalence and breed associations. Journal of Small Animal Practice, 61 (1), 32-41. doi: 10.1111/jsap.13067.

15. Mueller, R. S., Bensignor, E., Ferrer, L., Holm, B., Lemarie, S., Paradis, M., \& Shipstone, M. A. 


\section{ВЕТЕРИНАРНА МЕДИЦИНА}

(2012). Treatment of demodicosis in dogs: 2011 clinical practice guidelines. Veterinary Dermatology, 23 (2), 86-96. doi: 10.1111/j.1365-3164.2011.01026.x.

16. Sharma, P., Wadhwa, D. R., Katoch, A., \& Sharma, K. (2018). Epidemiological, clinicohaematological and therapeutic studies on canine demodicosis. Journal of Dairy, Veterinary \& Animal Research, 7 (3), 109-113. doi: 10.15406/jdvar.2018.07.00200.

17. Deepak, D., Chaudhary, A. K., Yadav, S., Das, A. K., Patel, P. K., Paul, B. R., De, U. K., \& Dixit, S. K. (2018). Clinical investigation and therapeutic management of canine demodicosis with doramectin: A case study. Journal of Entomology and Zoology Studies, 6 (6), 1012-1015. doi: 10.13140/RG.2.2.18337.97125.

18. Hsu, H. J., Feng, Z. H., Hsu, G. F., \& Kang, Q. Z. (1992). Survey of Demodex infections in the elementary and middle school students in LongHai City. Chinese Journal of Zoonoses, 8 (4), 54.

19. Desch, C. E., \& Hillier, A. (2003). Demodex injai: a new species of hair follicle mite (Acari: Demodecidae) from the domestic dog (Canidae). Journal of Medical Entomology, 40, 146-149. doi: 10.1603/0022-2585-40.2.146.

20. Gortel, K. (2006). Update on canine demodicosis. Veterinary Clinics: Small Animal Practice, 36 (1), 229-241. doi: 10.1016/j.cvsm.2005.09.003.

21. Kotelnikov, G. A. (1983). Gelmintologicheskie issledovanija zhivotnyh i okruzhajushhej sredy. Moskva [In Russian].

22. Cherepanov, A. A., Moskvin, A. S., Kotelnikov, G. A., \& Hrenov, V. M. (1999). Differencialnaja diagnostika gelmintozov po morfologicheskoj strukture jaic i lichinok vozbuditelej. Moskva [In Russian].

23. Bindari, Y. R., Shrestha, S., \& Shrestha, M. N. (2012). Prevalence of mange infestation in canines of Kathmandu valley. International Journal of Veterinary Science, 1 (1), 21-25. doi: 10.3126/ijasbt.v3i3.13218.

24. Tsai, Y. J., Chung, W. C., Wang, L. C., Ju, Y. T., Hong, C. L., Tsai, Y. Y., Li, Y. H., \& Wu, Y. L. (2011). The dog mite, Demodex canis: prevalence, fungal co-infection, reactions to light, and hair follicle apoptosis. Journal of Insect Science, 11, 76. doi: 10.1673/031.011.7601.

25. Chatterjee, A., Chattopadhyay, D., Gupta, D. N., \& Chakrabarti, A. (1980). An unusual association of Trichophyton mentagrophytes and Demodex canis in a mongrel dog with multiple kerions. Annals of Tropical Medicine and Parasitology, 74 (1), 101-102. doi: 10.1080/00034983.1980.11687317.

26. Chee, J. H., Kwon, J. K., Cho, H. S., Cho, K. O., Lee, Y. J., Abd El-Aty, A. M., \& Shin, S. S. (2008). A survey of ectoparasite infestations in stray dogs of Gwang-ju City, Republic of Korea. Korean Journal of Parasitology, 46 (1), 23-27. doi: 10.3347/kjp.2008.46.1.23.

Стаття надійшла до редакції 15.02.2020 р.

Бібліографічний опис для цитування:

Євстаф'єва В. О., Личман А. С. Особливості перебігу демодекозу у складі гельмінтозів травного каналу собак. Вісник ПДАА. 2020. № 1. С. 161-166.

(c) Євстаф’єва Валентина Олександрівна, Личман Аліна Сергї̈вна, 2020 